SOUTHERN BRAZILIAN JOURNAL OF CHEMISTRY

SOUTH. BRAZ. J. CHEM., Vol. 6, No 7, 1998

\title{
STUDY OF RENAL SORBITOLDEHYDROGENASE IN EXPERIMENTAL DIABETIC NEPHROPATHY
}

\begin{abstract}
Catalina Pisoschi*, Virgil Darie*, Mihai Serban ${ }^{\star *}$
* Biochemistry Department, Faculty of Medicine, University of Craiova, Petru Rares 4, Craiova, Romania

** Biochemistry Department, Faculty of Veterinary Medicine, Institute of Agronomy Bucharest, Romania
\end{abstract}

\section{ABSTRACT}

The link between the polyol pathway and the occular complications of diabetes mellitus is explained by the excessive storage of sorbitol and the release of osmotic stress. The renal complications could also be explained by the osmotic hypothesis, but the polyol pathway, activity is reduced in this case. The study of sorbitoldehydrogenase (SDH) activity, one of the enzymes involved in the catabolism of glucose by this pathway in renal and hepatic homogenates from diabetic animals shows a constant increase of the hepatic enzyme activity compared to that at the renal level. The different variation of the renal SDH activity can be explained by the effect of hyperglycemia on the active form of the enzyme and its inactivation by nonenzymatic glycosylation.

KEYWORDS: alloxan, polyol pathway, sorbitoldehydrogenase, aldose reductase, nonenzymatic glycosylation.

\section{RRSUMO}

A relasão entre o caminho metabólico do poliol e complicasões oculares de diabetes mellitus é explicado através da armazenagem excessiva de sorbitol e da liberagão da tensão osmótica. As complicasões renais também poderiam ser explicadas através da hipótese osmótica, porém a atividade do caminho do poliol está reduzida neste caso. O estudo da atividade da sorbitoldehidrogenase (SDH), uma das enzimas envolvida no catabolismo da glicose atraves deste caminho, em homogenatos renais e hepaticos, provenientes de animais diabéticos, mostra um aumento continuo da atividade da enzima hepática comparada à aquela a nivel renal. o comportamento diferente da SDH renal pode ser explicado através do efeito da hiperglicemia sobre a forma ativa da enzima e a sua inativasão por glicosilasão nonenzimätica. 


\section{INTRODUCTION}

Only a small percent of total glucose (aprox. 5\%) is transformed by the polyol pathway under normal conditions providing the sorbitol needed to maintain the hydroosmotic balance ${ }^{1,2}$. The polyol pathway is represented by two enzymes with different distribution:

- Aldosereductase (E.C.1.1.1.21), a NADP ${ }^{+}$dependent enzyme which acts in the medullary cells cytoplasm;

- Sorbitoldehydrogenase (E.C.1.1.1.14), a NAD ${ }^{+}$dependent enzyme from interstitial cells.

The two enzymes catalyse the transformation of glucose, first into sorbitol then to fructose (fig.1).

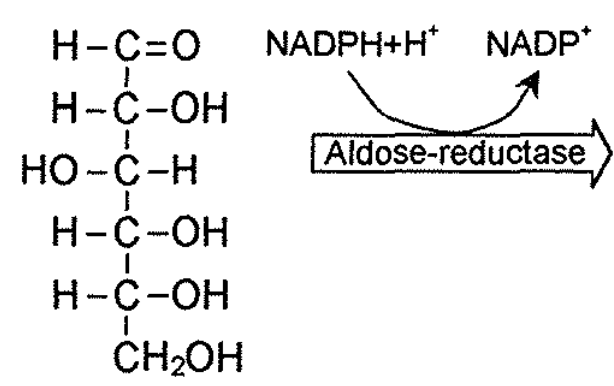

Glucose<smiles>OC[C@H](O)[C@H](O)[C@H](O)CO</smiles>

Sorbitol

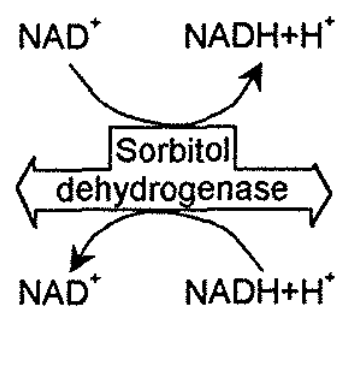

Fructose

Aldosereductase has a low affinity (high $K_{m}$ ) for glucose and, thus, at the normal concentrations found in non-diabetic conditions, the metabolism of glucose by this pathway constitutes a very small percent. During hyperglycemia the intracellular level of glucose is eleveted and the transformation by the polyol pathway is intensified because of the insulin deficiency (between $11-30 \%$ depending on the organ involved) $)^{3,4,5}$.

The storage of sorbitol and fructose in cells releases the osmotic stress ${ }^{6}$.

The polyol pathway has different activity in lens, liver, kidney, retina, large and thin vessels and peripheral nerves ${ }^{7}$.

The paper presents some of the results that we have obtained for renal and hepatic sorbitoldehydrogenase activity. They serve as an index for the polyol pathway in experimental diabetic nephropathy. The renal SDH activity depends on renal region, many data pointing out an increased activity in interstitial medullary cells ${ }^{8}$.

\section{MATERIAL AND METHODS}

The experiment was performed on 32 male Wistar rats, weighing $230-280 \mathrm{~g}$, kept under standardised feeding and bioclimatic conditions. To induce the experimental diabetes 24 of them were injected with a subcutaneous dose of $100 \mathrm{mg}$ 
alloxan $/ \mathrm{kg} \mathrm{b.w.} \mathrm{The} \mathrm{animals} \mathrm{were} \mathrm{divided} \mathrm{into} \mathrm{three} \mathrm{groups} \mathrm{and} \mathrm{sacrified} \mathrm{at} \mathrm{different}$ periods after the onset of diabetic state:

- Group I, after 4 weeks;

- Group II, after 6 weeks;

- Group III, after 8 weeks.

The other 8 rats were part of the control group (c).

We used blood, liver and kidney samples to test the activity of sorbitoldehydrogenase.

Tissue homogenates were obtained in Tris- $\mathrm{HCl}$ buffer $\mathrm{pH}=7,5$ with an extraction ratio tissue/buffer $=1 / 10$ method $^{9}$.

We tested the sorbitoldehydrogenase activity with the Richterich's colorimetric

The total amount of tissue proteins was measured by the Lowry's method ${ }^{9}$. method.

Serum glucose was measured by means of the o-toluidine colorimetric

\section{RESULTS AND DISCUSSIONS}

The experimental results, statistically processed, are illustrated in Table 1.

Soon after the alloxan administration we determined a triphasic variation of glucose values before the permanent hyperglycemia.

Figures 2 and 3 present the variation of hepatic and renal SDH activity for the three groups of treated animals compared to the control group.

Data from Figure 2 and Table 1 show a significant increase of hepatic SDH activity for the treated animals compared to the control group. The sorbitol pathway is a metabolic alternative for glucose in hyperglycemic conditions which follow the insulin deficiency in experimental diabetes.

This variation explains the hepatic origin of this enzyme.

At the same time, the alloxan "agression" also exacerbates the polyol pathway and the synthesis of the enzymes involved in this pathway increases in liver cells.

The high amount of sorbitoldehydrogenase in the liver was also confirmed by the increased concentration of SDH $m-$ RNA $^{10}$.

The renal sorbitoldehydrogenase shows a different variation when compared to the hepatic enzyme (Table 1 and Figure 3).

Renal SDH activity increased for groups I and II compared to the control group, but the group III presented reduced activity.

Renal SDH activity increase is less significant as compared to the hepatic enzyme. Also, its variation doesn't correlate with serum glucose level.

The increased value of renal SDH activity is explained by the intensification of the polyol pathway and its decrease is caused by an intense glycation process.

Hyperglycemia enhances the nonenzymatic glycation of intracellular constituents and the active form of renal sorbitoldehydrogenase is transformed into an inactive one. 
Table 1

LEVELS OF SOME PARAMETERS IN EXPERIMENTAL DIABETIC NEPHROPATHY

\begin{tabular}{|l|c|c|c|c|}
\hline \multicolumn{1}{|c|}{ Parameter } & $\begin{array}{c}\text { Control group } \\
(\bar{x} \pm \text { SD })\end{array}$ & $\begin{array}{c}\text { Group I } \\
(\bar{x} \pm \text { SD })\end{array}$ & $\begin{array}{c}\text { Group II } \\
(\bar{x} \pm \text { SD })\end{array}$ & $\begin{array}{c}\text { Group III } \\
(\bar{x} \pm \text { SD) }\end{array}$ \\
\hline Serum glucose $(\mathrm{mg} / \mathrm{dl})$ & $79.34 \pm 1.64$ & $300.4 \pm 6.3$ & $260.3 \pm 4.2$ & $374.2 \pm 0.65$ \\
\hline Hepatic SDH $^{*}$ & $6.8 \pm 1.3$ & $9.2 \pm 2.4$ & $13.4 \pm 0.6$ & $16.5 \pm 1.7$ \\
\hline Hepatic SDH variation compared to the normal group & - & $135 \%$ & $195 \%$ & $240 \%$ \\
\hline Renal SDH & $0.78 \pm 0.12$ & $0.81 \pm 0.92$ & $0.98 \pm 0.24$ & $0.80 \pm 0.42$ \\
\hline Renal SDH variation compared to the normal group & - & $105 \%$ & $120 \%$ & $102 \%$ \\
\hline
\end{tabular}

* SDH activity is measured in $\mu$ moles fructose $/ \mathrm{min} / \mathrm{g}$ of protein 
SOUTH. BRAZ. J. CHEM., Vol. 6, No 7, 1998

C. Pisoschi, V. Darie \& $M$. Serban

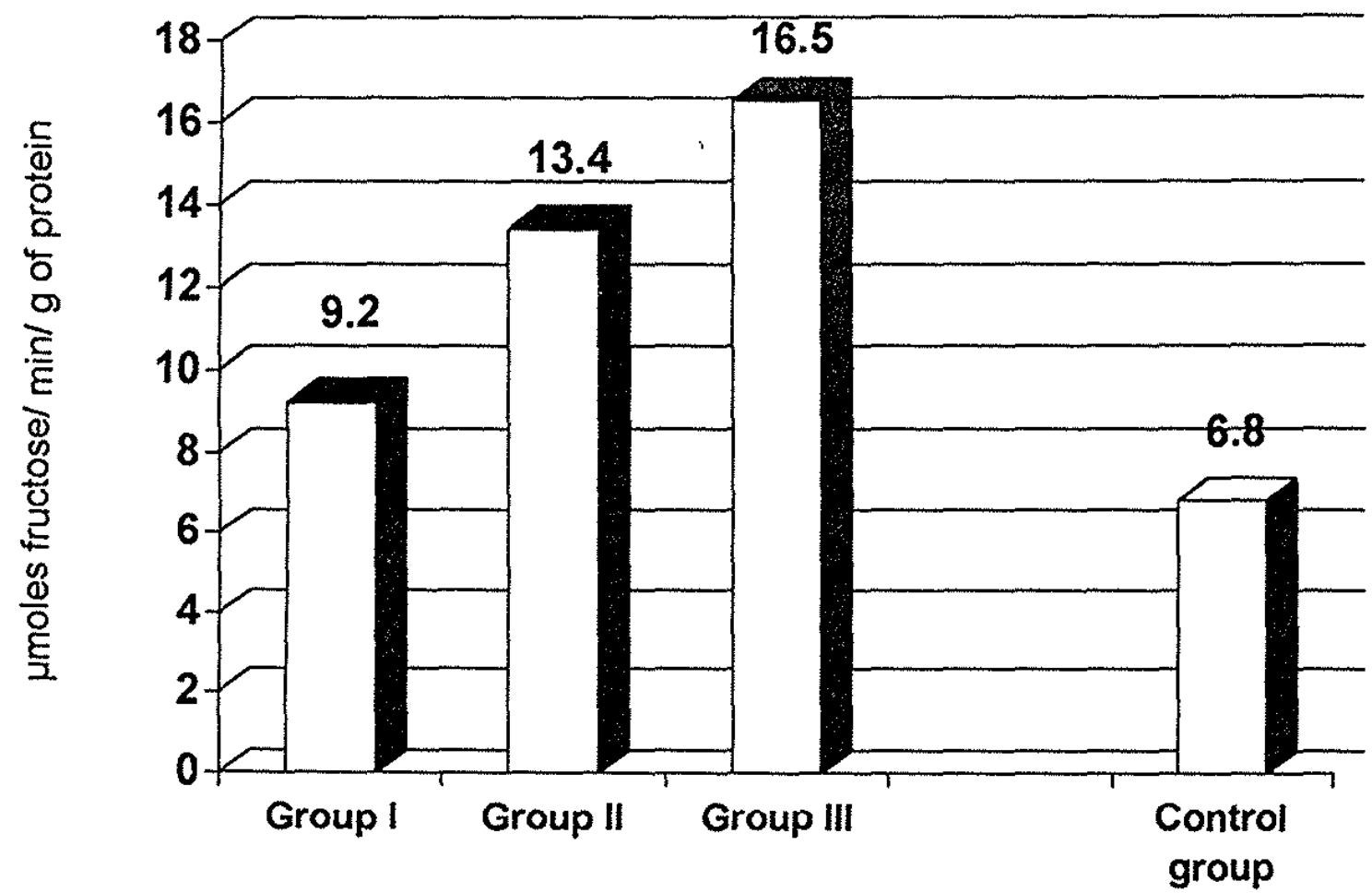

Fig.2. Variation of hepatic SDH activity

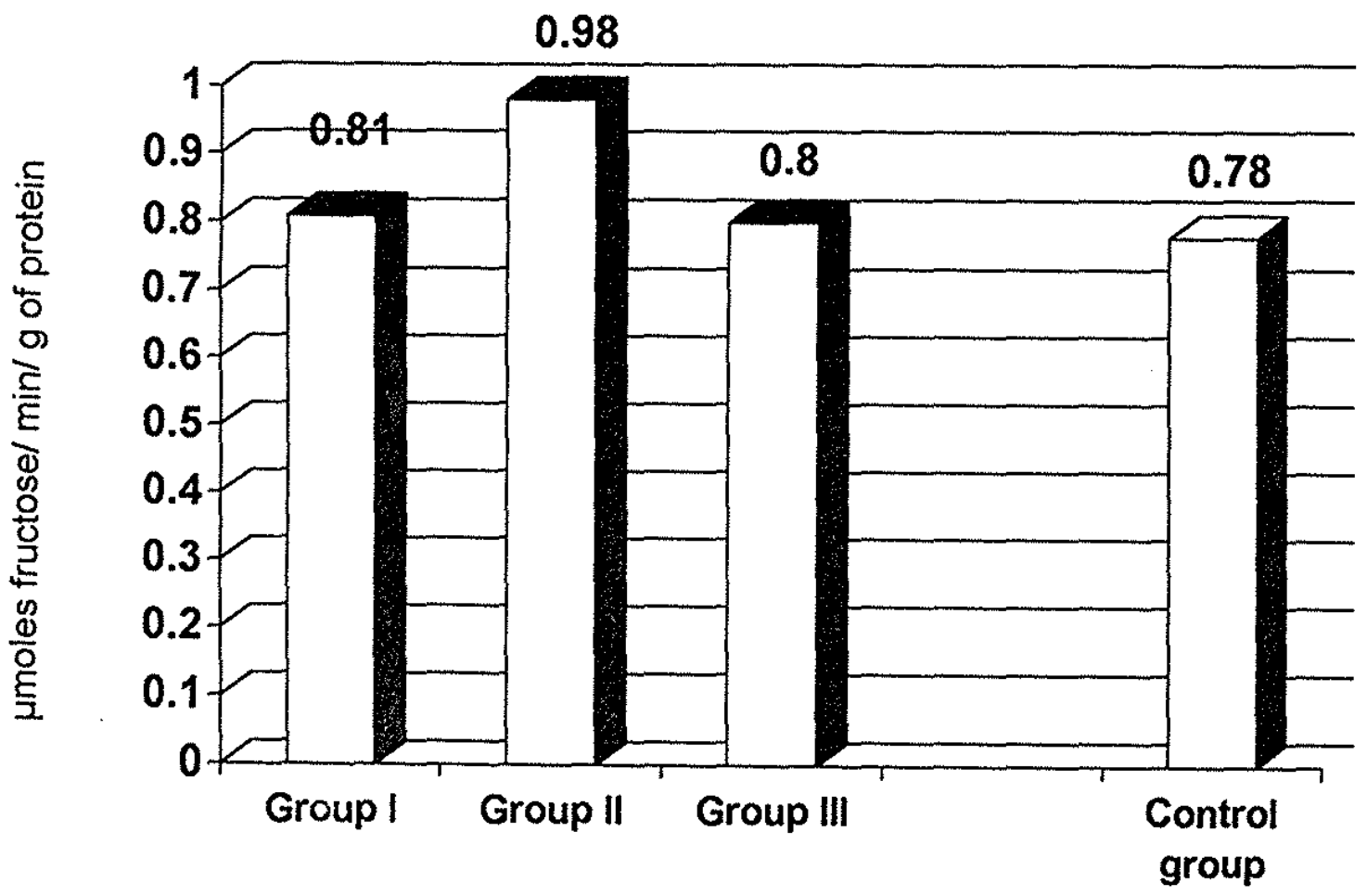

Fig.3. Variation of renal SDH activity 
SOUTH. BRAZ. J. CHEM., Vol. 6, $\mathbf{N}^{\circ} 7,1998$

\section{CONCLUSIONS}

- The study of the polyol pathway intermediates and enzymes from the renal tuft is very important to explain the mesangial alterations associated with the renal complications of diabetes mellitus.

- The experimental model of diabetic nephropathy presents some similar conditions with diabetes mellitus caused by insulin deficiency.

- Both the activity of the enzymes involved and the relative preponderance of the polyol pathway intermediates showed changes.

- Although the SDH activity is modified, its variation does not correlate with hyperglycemia.

\section{REFERENCES}

1. I. Teodorescu-Exarcu, Patologie biochimica. Editura Medicala, Bucuresti, Romania, 1974.

2. C. Ionescu-Tirgoviste, Diabetologie moderna. Editura Tehnica, Bucuresti, Romania, 1997.

3. R. G. Gonzales, R. Barnett, J. Agnuyo, H. M. Cheng, L. T. Chylack, Diabetes, 33, 196-199 (1984).

4. J. H. Kinoshita and C. Nishimura, Diabetes Metabolism Rev., 4, 323-337 (1988).

5. N. B. Ruderman, J. R. Williamson and M. Brownlee, FASEB J., 6 , 2905-2914 (1992).

6. D. A. Greene, S. A. Latimer and A. F. Sima, New Eng. J. Med., 316, 77, 599-606 (1987).

7. V. Darie and M. Serban, St. Cerc Biochim., 24, 157-160 (1981).

8. R. W. Grunewald, J. J. Weber and R. K. Kinne, Am. J. Physiol., 269, 696-701 (1995).

9. R. Richterich. Clinical Chemistry. Theory and Practice. Academic Press New York, London, 1969.

10. A. Hoshi, M. Takahashi, J. Fuji, T. Myint, H. Kaneto, K. Suzuki, J. Jamasaki, T. Kamada, N. Taniguchi, Biochem. J., 318, 119-123 (1996). 